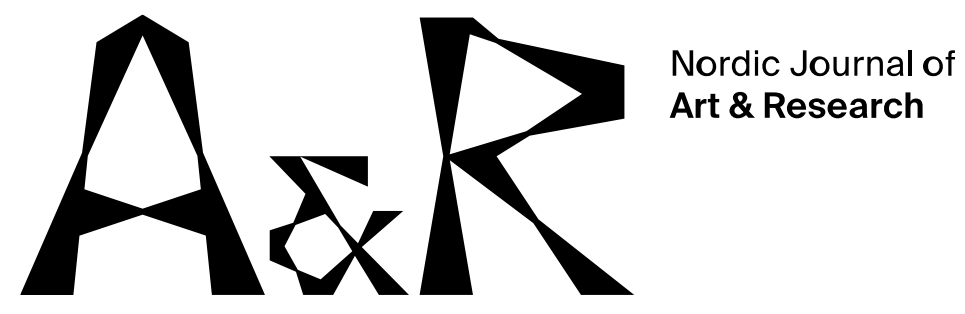

\title{
Haugerudbekken: Community improvement through socially engaged art
}

\author{
Katja Høst and Liva Mork ${ }^{1}$ \\ Independent artists
}

\begin{abstract}
Haugerudbekken is the collective title of a series of art projects where two local artists (the authors of this article) collaborate with pupils from local schools in Haugerud to create public art installations in the neighbourhood. Haugerudbekken may be considered a practical exploration guided by principles in the fields of socially engaged art (SEA), teaching artists (TA) and community artists (CA). The project is being undertaken within the broader context of a government run local improvement initiative in the Oslo suburbs of Haugerud and Trosterud. A growing demand for art entering a societal context (like urban development) calls for approaches emphasizing dialogue, communication and local affiliation. As this demand grows, so does the need for best-practice guidance for initiating artists as well as for policymakers and others inviting artists to contribute. Furthermore, our approach as independent artists working within a community setting might also benefit from clarification of theory and framework in this field.
\end{abstract}

This article therefore aims to share knowledge gathered through our three years (and still ongoing) working on Haugerudbekken, pinpointing what we believe to be key success factors as well as challenges in our project. Findings are discussed in

${ }^{1}$ katjahost@gmail.com, livamork@hotmail.com 
relation to existing theory and relevant practice in SEA, TA and CA informing existing guidelines as well as terminology.

Keywords: relational aesthetics, socially engaged art, teaching artist, community artist, artistic research, practice-based research, practice-led research, public art, community improvement

\section{Introduction}

Haugerudbekken is the collective title of a series of art projects where two local artists (the authors of this article) collaborate with pupils from local schools in the Oslo suburb of Haugerud to create public art installations in the neighbourhood. The title Haugerudbekken refers to the initial starting point of the project: a stream hidden below ground and unknown to most residents in the area. Like many other streams in this originally farmland area, the stream was laid in pipes as the area underwent urban development in the 1960 and 1970s. The first public art production from this collaboration was a 400-meter-long 'stream' of spring flowering Crocus vernus (planted in autumn 2017 and 2018) running through two large condominium complexes. This was followed by a photography installation (spring 2018), a sound installation (spring 2019), and a project addressing the new schools to come (spring 2019), thus expanding the project into a larger ongoing reflection around past, current and future qualities of the neighbourhood.

The project is being carried out in a new era of development. The City of Oslo's Agency for Planning and Building Services is currently drawing up new zoning plans for Haugerud and Trosterud, and the City of Oslo is running a community improvement project (områdeløft). This context accentuates Haugerudbekken's inherent focus on local influence and participation in community development. Through artistic practice, the project aims to contribute quite literally in the discussion of what Haugerud is and can be, and specifically to engage local children in this discussion through artistic collaboration. An additional aim for the project was to strengthen the presence of art in the neighbourhood, not only in terms of accessible public art but also by expanding the somewhat limited offering of cultural activities for children in the area. 


\section{Theoretical framework, method and research questions}

Haugerudbekken may be considered a practical exploration guided by principles within the field of relational aesthetics. ${ }^{2}$ Relational aesthetics refers to a broad spectrum of practices with overlapping terms such as social practice, public practice, participatory art and dialogical aesthetics (Atkins, 2013, pp. 226-228). A unifying principle across this spectrum is the notion that the process is equally important as the result, and the dialogue, discussions and exchange of ideas are key elements. The fact that we, the initiating artists, belong to the local community where our work is developed is believed to support these aspects within relational aesthetics.

We particularly identify our process with the principles and guidelines outlined by Helguera in his book Education for Socially Engaged Art (2011). He describes socially engaged art (SEA) to function 'by attaching itself to subjects and problems that normally belong to other disciplines, mowing them temporarily into a space of ambiguity' (p. 5). As we invite the children to reflect on Haugerud's current identity in relation to its past as well as to its potential future, we aim to create such an ambiguity, inviting questions in relation to the current development plans.

Furthermore, Helguera stresses the fact that SEA operates in an expanded field, sometimes guided by knowledge from other disciplines such as pedagogy, theatre, anthropology etc. (p. x). In Haugerudbekken this expanded field includes community improvement as well as education.

According to Helguera, education is a particularly fruitful field to extract knowledge from in SEA ( $p . x i$ ), given its inherent focus on collaborative dialogue, inquiry and engagement with the audience. This resonates with our approach in Haugerudbekken, where we explicitly emphasize collaboration with children to produce art. We invite them to develop the project through workshops organised at local schools, entering further into the field of education. However, although we are working with children and youth in schools, it is important to point out that we are artists, not teachers or educators, and our approach towards the children is that of professional artists. Marit Ulvund proposes the following definition for professional artists entering a community or educational setting and engaging non-professional audiences; 'A teaching artist is a professional artist with the competencies needed to

\footnotetext{
${ }^{2}$ First described by Nicolas Bourriaud, author of the book Relational Aesthetics, as 'A set of artistic practices which take as their theoretical and practical point of departure the whole of human relations and their social context, rather than an independent and private space' $(1998,1998$, p. 113).
} 
work in and through the arts in an educational and/or community setting' (2015, p. 33). Her model and definitions of teaching artists (TA) will be addressed in relation to our work, aiming to clarify our position in Haugerudbekken. This includes addressing the somewhat blurred distinction between teaching artist and community artist (CA), often performed as a hybrid, with the latter described as an artist who involves and/or enriches community life through artistic practice (Booth, 2010; Tate, 2020).

Haugerudbekken also raises interesting questions in relation to art didactics within education. However, the limited scope of this article does not allow a broader discussion of these aspects.

Haugerudbekken was originally undertaken as an independent art project, with no explicit intention to conduct research. However, a growing demand for art entering a societal context (like urban development) calls for research addressing theory and improving best-practice guidance for initiating artists as well as policymakers and others inviting artists to contribute (Christensen-Scheel, 2013). Haugerudbekken's practical explorative nature generates knowledge in relation to SEA in the context of urban development and sharing reflections from our process may inform theory and further practice contributing to a continuing cycle where practice informs theory, and theory informs practice (Engen, in review).

According to Hovik (2014), the term practice as research (PAR) is the most widely used term for a wide spectrum of research adhering to the following joint notion: the creative work in itself as a form of research, with the potential to generate new knowledge (p. 97). Within PAR, experience-based knowledge may become research when shared and reflected in a context and theory-sensitive way (Engen, in review; Rasmussen, 2012). However, Candy \& Edmonds (2018) address possible confusion arising from the use of the term PAR, as the distinction between practice and research might be unclear within creative arts. Most artists find their art to explore new territory, generating knowledge, but in order to become research, such new knowledge needs to be reflected on, shared and put in context with existing theory and practice (Candy \& Edmonds, 2018; Engen, in review; Rasmussen, 2012). Sharing of practice-generated knowledge in order to guide best practice, as we aim to do in this article, are by some termed practice-led research (Candy \& Edmonds, 2018; Engen, in review; Hovin, 2014). Candy \& Edmonds, however, suggest a distinction between practice-led versus practice-based research, with the latter term being 'especially useful where the creation of artifacts materially affects the way the process is carried out, and the kinds of outcome that emerges" (p. 65). In Haugerudbekken we find such a feedback loop between the different subprojects, where experience and reflections in the aftermath of one project feed into the next 
one in a cyclical loop. Furthermore, the significance of the actual artefacts produced in terms of public art holds a key place in our project, also highlighted within practicebased research as defined by Candy \& Edmonds.

A/R/Tography, a method for practice-based research within art and education, also deserves a mention, since Haugerudbekken ventures into the field of education and research as well as art. However, we find this term somewhat misleading for Haugerudbekken, as A/R/Tography attaches equal weight to the different (albeit overlapping) roles of artist, researcher and teacher, indicated in the lettering of $A / R / T$ (Irwin et al., 2006; Irwin et al., 2017). We consider ourselves first and foremost to be practitioners, and find that Haugerudbekken meets the defining qualities of practiceled as well as practice-based research. Hence, we turn to the broader but much used term of artistic research (AR) (Hovik, 2014; Østern, 2017). Highlighting AR as a broad term, even suggesting a final definition impossible given the field's tendency to resist definitions, de Assis \& D'Errico emphasize one unifying feature of AR as its focus on practice: 'it is practice-based, practice-led, and practice-driven. It is also a mode of research conducted by practitioners, by doers - be it musicians, artists, writers, or even 'practicing' philosophers' (2019, p. 3). For Haugerudbekken, which started as a public art project and where education and research became part of the process over time, AR then seems the most appropriate term when defining our research method.

This article aims to share knowledge gathered through our three years (and still ongoing) of working on Haugerudbekken, pinpointing what we believe to be key success factors as well as challenges in our project. Findings will be discussed in relation to relevant theory and practice within SEA, TA and CA. Research questions addressed are: how can employing SEA aid/contribute to and generate reflection within local improvement initiatives? How can such a practice engage children, and what are the key success factors? Can SEA help improve communities while retaining the status of autonomous art, and what are the key challenges? Given the important context of community improvement in our project, we begin with a brief presentation of the area we work in and our connection to it.

\section{Haugerud and Trosterud where our project takes place}

The suburbs of Haugerud and Trosterud, housing approximately 19000 people, are situated in northeast Oslo, bordering on the surrounding forest. Originally an old farm and cottage district, the area was transformed into massive condominium developments, a subway station and a shopping centre during the1960s and 1970s. Today, Haugerud and Trosterud are marked by large concrete condominium complexes, with paved areas or lawns in between. The area is still draped by the 
forest to the north and east, and the proximity to nature is one of its foremost qualities (Skajaa, 2015). However, few visual traces remain of this inherent quality in the urban housing areas or the public spaces in Haugerud and Trosterud, rendering a major identity marker of the neighbourhood more or less invisible.

Current demographics indicate social economic challenges. There are $79.1 \%$ $(2018 / 2019)^{3}$ minority children in the local primary school, speaking 40 different languages. ${ }^{4} 20.5 \%$ (2017) of children here grow up in low-income families, and $34.2 \%$ of them live in overcrowded spaces (2015). Overall, the area has certain social challenges and hosts a diverse community. Furthermore, much of the public infrastructure and buildings are worn down and in need of renovation or renewal. Hence, the City of Oslo arranged community improvement initiatives in Haugerud and Trosterud, starting in 2017 (Oslo kommune, Områdeløft Trosterud og Haugerud). In addition, Oslo has a housing shortage, and Haugerud and Trosterud are considered to be low-density areas (Oslo kommune, Planprogram for Trosterud og Haugerud), so a new zoning plan for the whole area is currently on the drawing board. This new zoning plan includes two new much needed public school buildings as well as a new recreation centre (flerbrukshall) in addition to overall densification of housing areas.

Both artists working on Haugerudbekken live in Haugerud, and we met through the local network established through some of these improvement initiatives. Hence, our project developed from, and has become an integrated part of the area development. We wanted to address some of the needs and challenges we as inhabitants experience first hand. First, we believe that the inherent qualities of Haugerud are not contributing as much to local pride and positive ownership as they could by remaining visually 'hidden' in the housing areas. Furthermore, we found that cultural activities for children and youth in the area were lacking. For instance, the Oslo School of the Arts (Oslo kulturskole) ${ }^{5}$ was not represented with a local venue (kulturstasjon) in the district of Alna when our project started, unlike most other districts in Oslo, despite being relatively large and densely populated. This could be related to the challenging socioeconomic profile of Alna, since high participation costs in the School of the Arts

\footnotetext{
${ }^{3}$ The statistics presented were gathered in January 2020 from the City of Oslo's public website: Statistikkbanken Oslo kommune. Statistics for the most recent year available were chosen.

${ }^{4}$ https://trosterud.osloskolen.no/om-skolen/om-oss/var-profil/

${ }^{5}$ Oslo School of the Arts: a resource centre for art education for children and youth in Oslo providing professional applied education for children in music, dance, theatre and visual arts. Classes are offered at local culture centres for children (kulturstasjoner) located throughout the city.
} 
have been shown to prevent low income families from signing their children up (Bjørnsen, 2012; Bamford 2011; Gustavsen \& Hjelmbrekke, 2009).

We both became involved in local community improvement initiatives and wanted to draw on our resources as professional artists in these processes. We wanted art to have a stronger presence in the area in terms of accessible, public art as well as an improved offering of art-based activities for children. In addition, we observed that children as a group were not really included in the participation initiatives arranged by the City of Oslo as part of the local development programme.

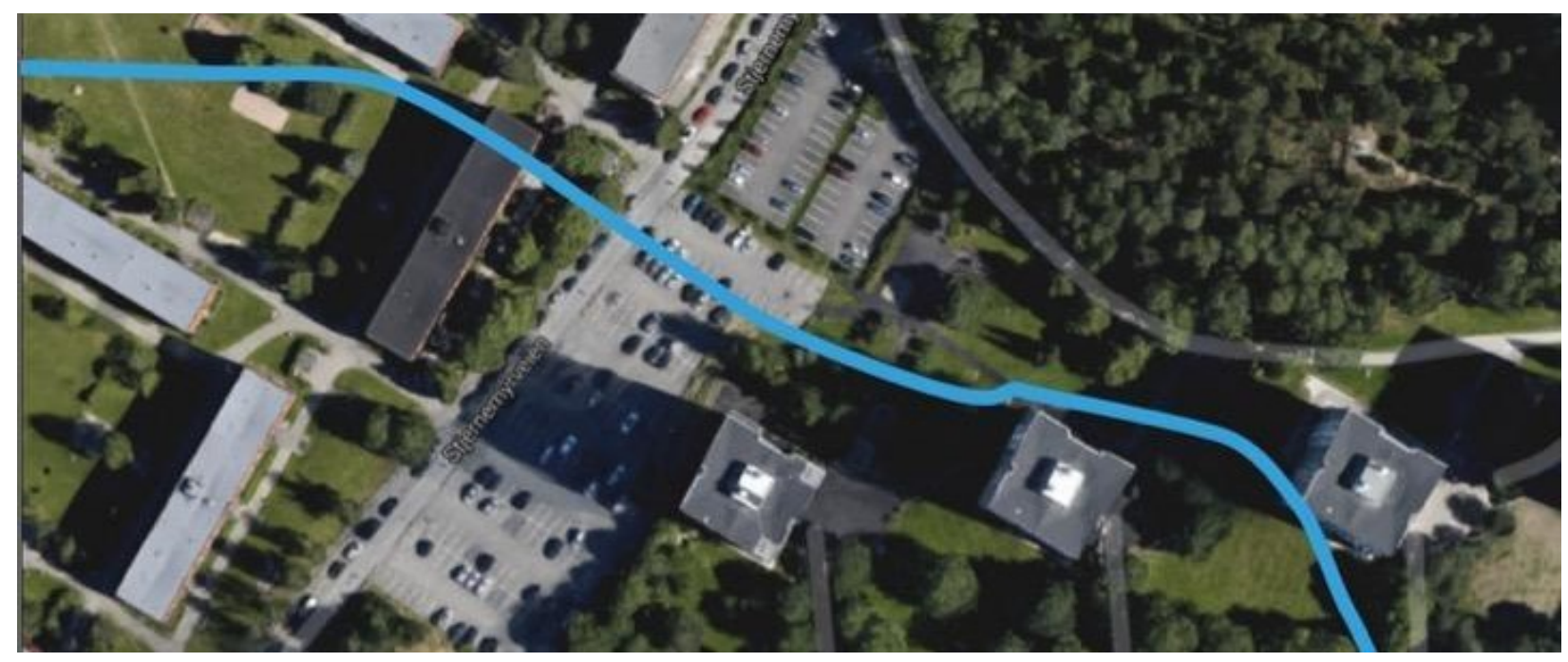

Figure 1. Research draft produced for the first project in Haugerudbekken. The stream hidden in pipes is marked on an excerpt of the map, showing parts of two large condominiums in the area. February 2017. Photograph: Illustrator drawing on map from Google Maps.

\section{Two examples of projects within Haugerudbekken}

\section{Haugerudbekken}

At a local resident's association meeting, one of the artists learned about the original stream called Haugerudbekken and formed the idea of marking it in the current landscape. Meeting a fellow artist with experience from working with children as coproducers of art sparked the idea of developing such a project together with local children. We then wanted to develop ideas for marking the pathway of the original Haugerudbekken stream through the suburban landscape of Haugerud. Furthermore, we wanted to produce it as a public art piece so as to create a visual marker of Haugerud's close connection to the forest as the history of its landscape, inviting local residents to reflect on the past, current and future development of the area.

Given our wish to involve children and at the same time offer art-related activities free of charge, it seemed natural to approach the local schools. We, the artists, defined the framework for the workshops together with the school administration. All 
schoolchildren in grades 3 and 4 who attended the after-school activities programme were given a presentation of the programme for the project and given sign-up sheets to bring home to their parents. A total of 25 children signed up, and we divided them into two groups.
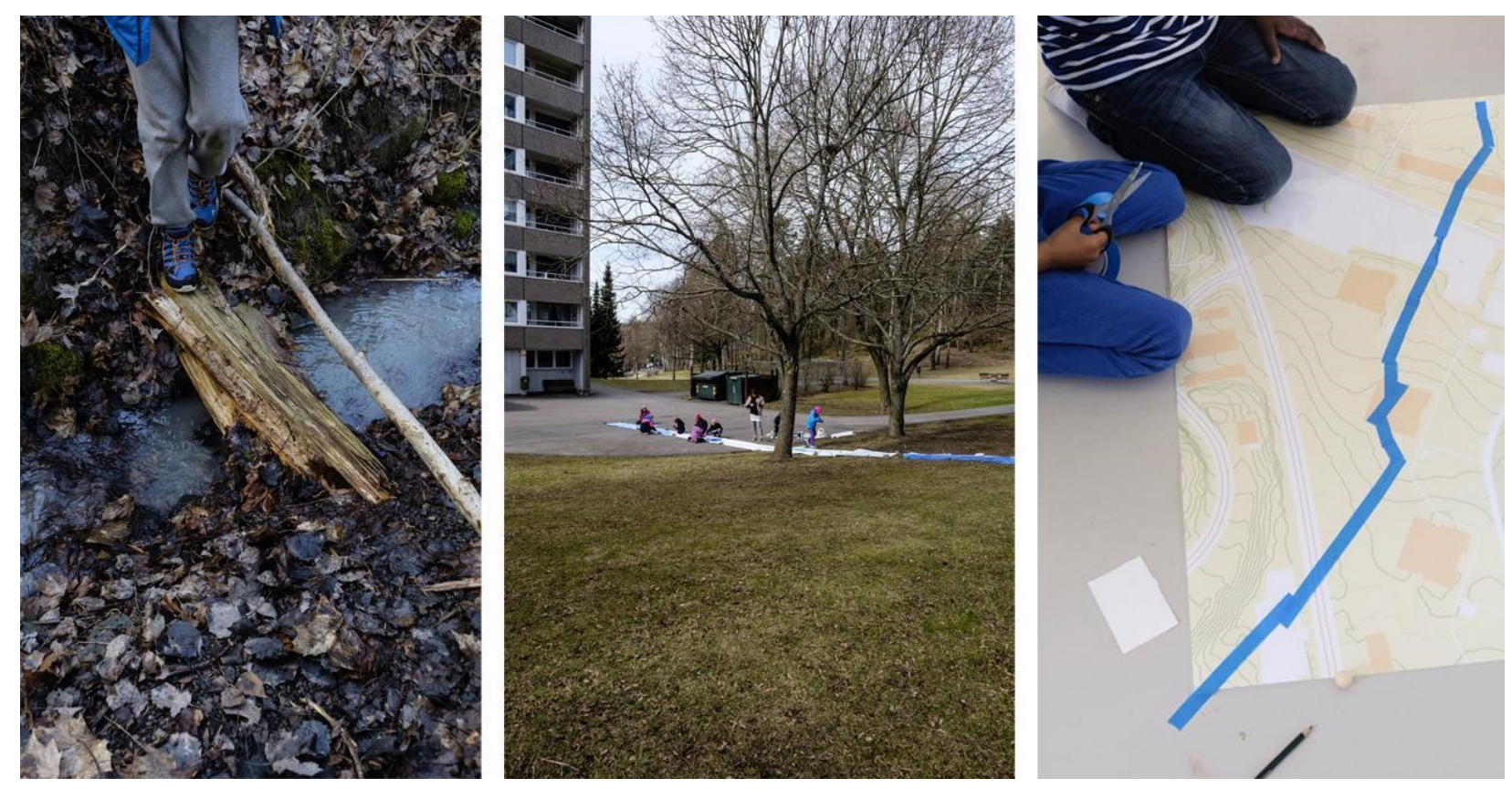

Figure 2. From the first project in Haugerudbekken, working in the landscape (the forest and in Solfjellet condominium) and with the map (at a studio space for artists that we rented for the workshop at the old Trosterud Farm). March and April 2017. Photograph: Katja Høst.

We started out by telling the children about the stream and followed up by exploring a section of the landscape it runs through on a large map. The children were asked to make drawings of themselves and to pin them onto the points on the map indicating where they lived, so as to place themselves in relation to the hidden stream. We later went into the landscape, and the children marked the area where the stream is visible and where it disappears underground using paint and elements such as sticks, pine cones and rocks found nearby. One of our favourite moments during this research phase was when we were painting on large rolls of paper on the ground above where the stream is hidden. Residents walking past would stop and ask the children what they were doing, and they would explain about the stream hidden in pipes.

Spontaneous discussions of landscaping and development thus occurred between the children, local inhabitants and the artists. 

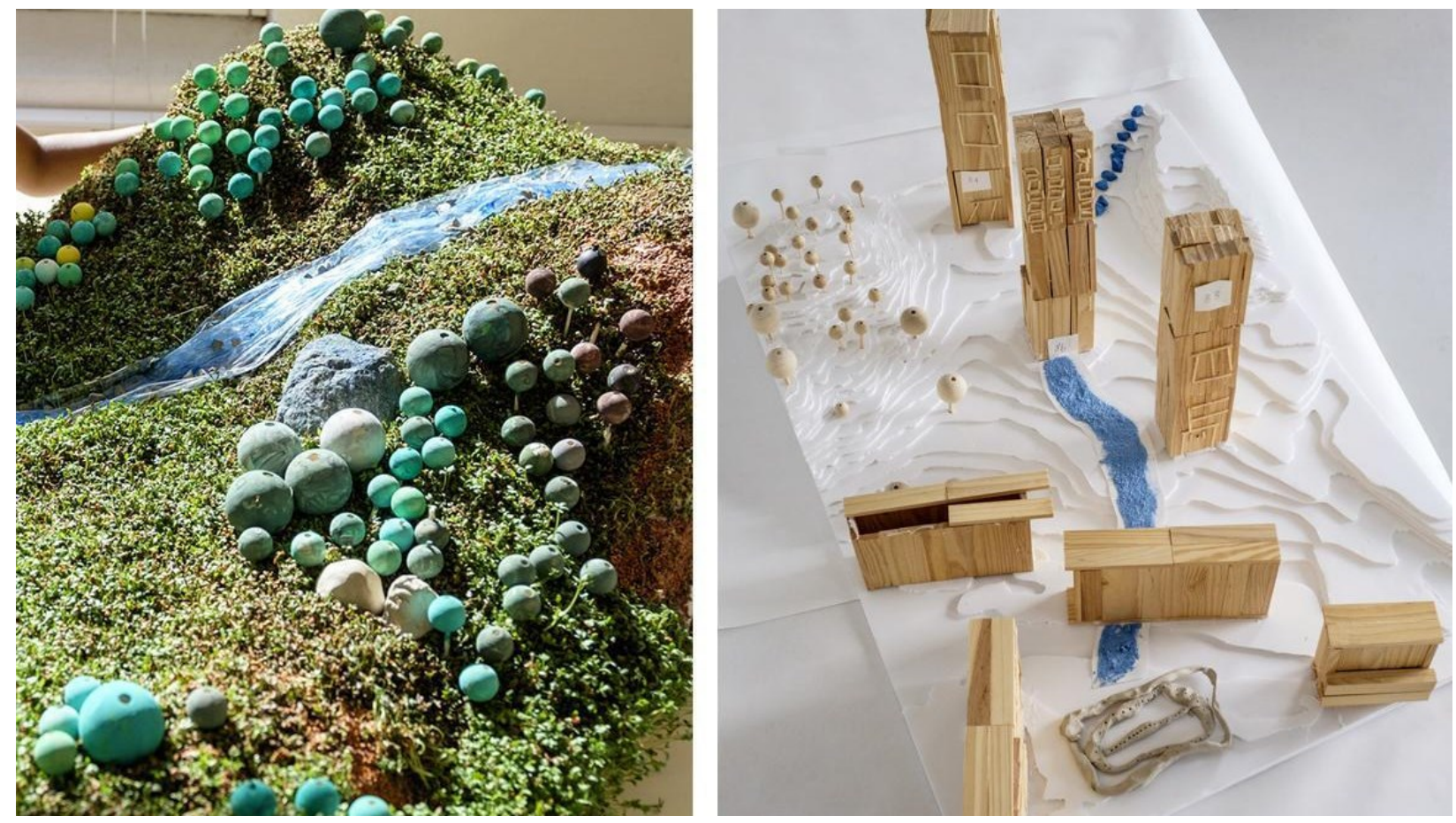

Figure 3. From the first project in Haugerudbekken, two models, one historical and one contemporary. May 2017. Photo: Katja Høst.

After a process of research and investigation, we developed ideas for marking the current landscape and presented them using two models created by the children, one of the historical landscape and one of the current landscape. The children had several ideas on how to mark the landscape, but only some of these could be fitted into the model. We therefore held a vote over which ideas to present resulting in: painting a blue stripe on the ground, placing blue elements (like rocks) and creating a water fountain. The remaining ideas were written down on a sheet of paper and presented alongside the two models and artefacts produced throughout the whole period in an exhibition that was open to family and friends.

In order to transform the children's ideas into a public art piece, it had to be fairly easy to maintain, financially realistic and not prevent other types of maintenance in the condominiums. Hence, after holding the course and reviewing the different ideas, we opted for the one for planting blue flowers. The following two autumns, in collaboration with children from the school as well as residents in the Haugerud and Solfjellet condominiums, we planted 37000 Crocus vernus bulbs to form a 400metre-long 'stream' running through an area with a total of 24 condominium buildings. Every spring, the 'stream' flowers, reminding residents and passers-by of the area's connection to the lakes in the woods as well as to the river Alna. It also serves as a 
reminder of the history of the area, and most importantly, it reminds the children who live there that they can participate in shaping the future.

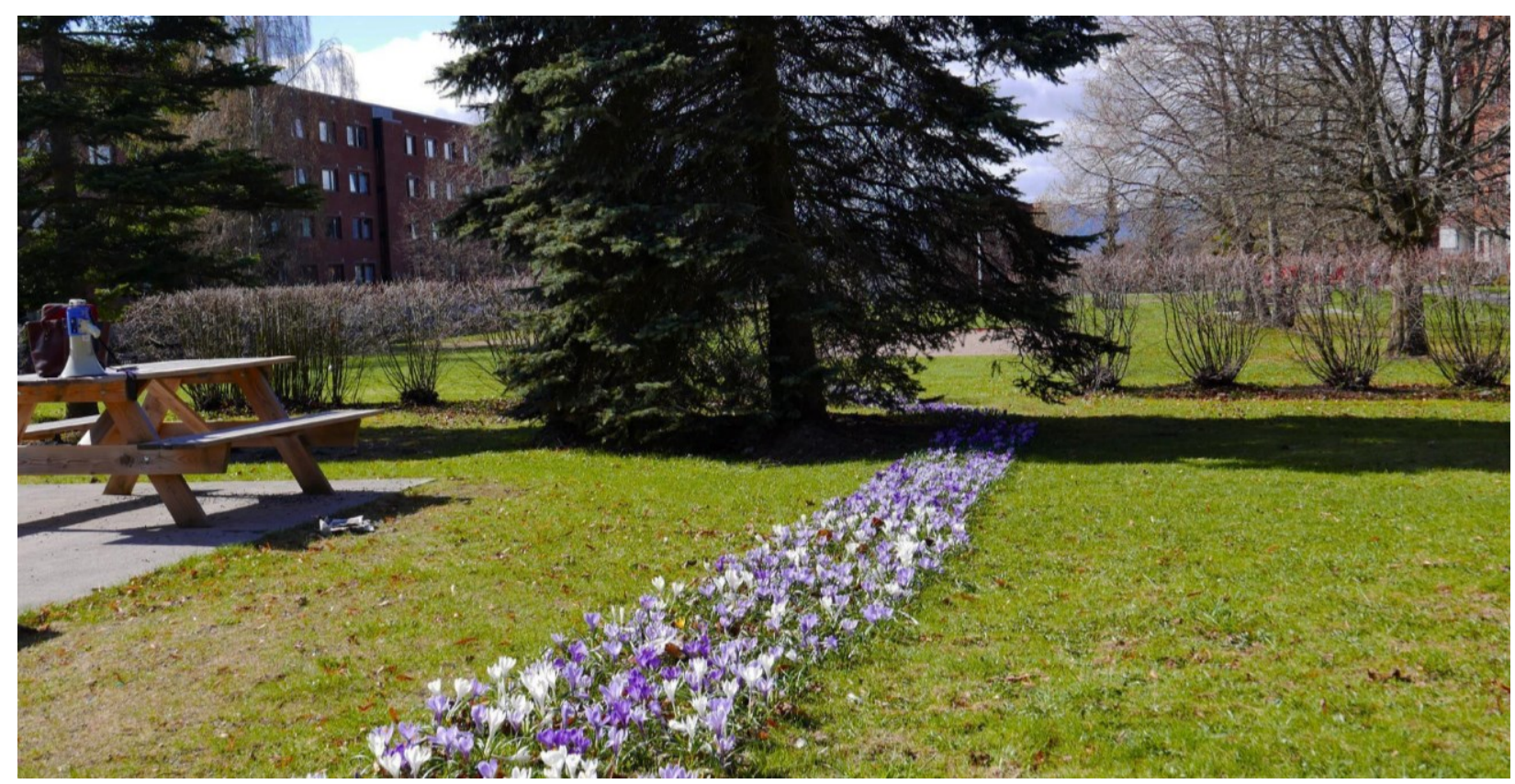

Figure 4. From the first project in Haugerudbekken, the flowering stream. April 2018. Photo: Ingrid Økland @) Kulturbyrået Mesen.

\section{New school}

Participating in shaping the future lies at the core of the fourth subproject in the Haugerudbekken project, titled New School (Ny skole), accentuating the notion of exchange and dialogue within SEA. As Haugerud and Trosterud are on the drawing table for a new zoning plan, part of this plan is to build two new schools (a primary and a secondary school) to replace the current schools, which are rather dilapidated. In these workshops we concentrated on the new primary school, collaborating with second-grade schoolchildren. The Agency for Real Estate and Urban Renewal has offered an open and including process throughout the local community, asking for our views on the new plan, but in this process we found that the children's voices were missing. 

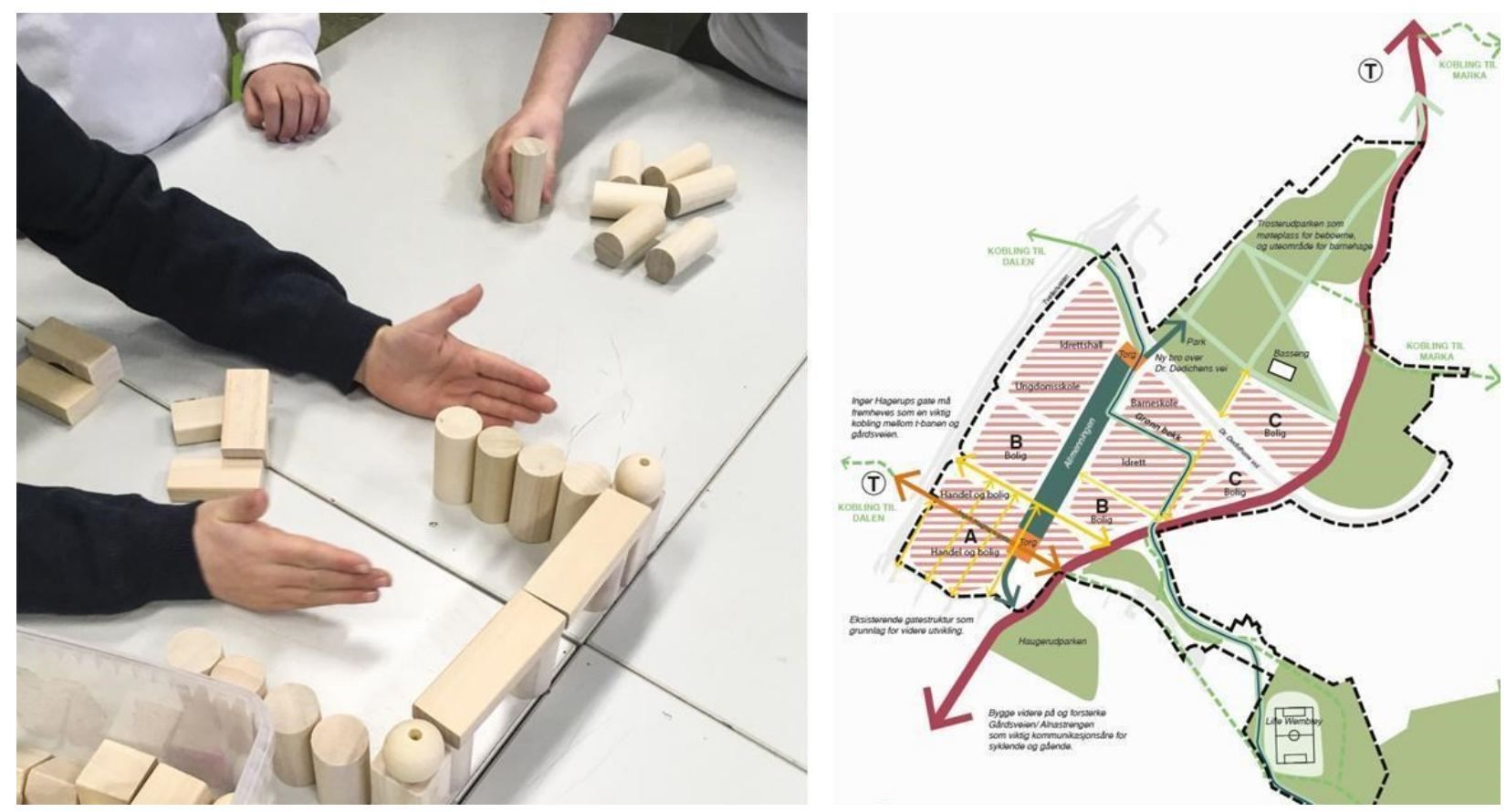

Figure 5. From the third subproject, New School, drafting school models. March 2019. Photograph: Katja Høst. Map retrieved from Byrådssak 31/19, City of Oslo.

We thought it would be interesting to hear from the children who used the school every day as their arena for learning, playing and social interaction. What are the central elements that should be in place for making it a safe and inspiring place for them? From this perspective, the children might be regarded as experts, so we invited them to share their knowledge and experience through workshops, focusing on basic forms, constructions and architecture and making proposals for a new primary school. We visited the site where the new school is to be built and tested how to incorporate architecture into these surroundings. Only a few of the children knew that a new primary school was to be built and none of them knew where it was to be located.

During the workshops the children created five models focusing on the building, the playground and the building's interior, and on how to incorporate and use the roof of the building. The children's ideas included a dinosaur slide, a roof garden playground including an outdoor kitchen and a telescope, a diving board with access directly from the classroom window into a swimming pool, and an entire school building shaped like a slice of watermelon. 

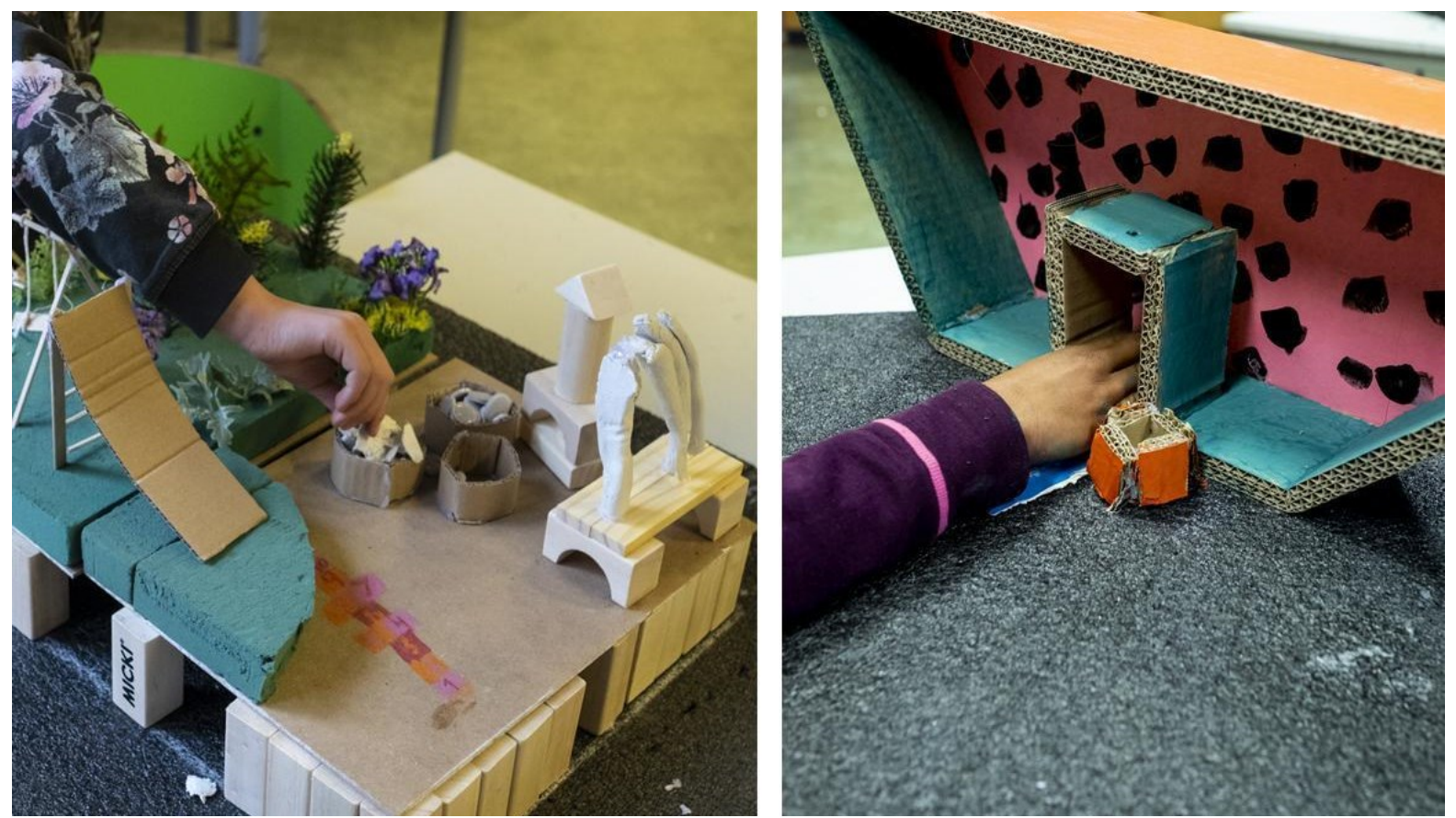

Figure 6. From the third subproject, New school, building models for presentation. April 2019. Photograph: Katja Høst.

These ideas may sound somewhat spectacular, and if an architect should take them into account, transforming them into realistic alternatives would prove challenging. However, they are still an expression of what the children feel they are lacking in their school today. As mentioned earlier, their current school has seen better days. In 1972 the ground-breaking sculpture Havbølger by Siri Aurdal (born 1937) was unveiled, accommodating play ${ }^{6}$. Hence, the multitude of ideas linked to green areas as well as to other structures suitable for play that were suggested by the children are not surprising and should be taken into account in future planning. Furthermore, ideas such as a quiet room to relax in and a way of looking at the stars are not so difficult to implement.

We produced a publication that documented and summarised all the children's proposals and ideas and, together with the children, we visited GASA, the architectural firm assigned to draw the new school. The Education Agency of Oslo and the Municipal Undertaking for Educational Buildings and Property also attended this meeting, and the children presented their models and ideas and handed over the publication. In the aftermath of this subproject, the Education Agency of Oslo has

\footnotetext{
${ }^{6}$ https://nkl.snl.no/Siri Aurdal
} 
suggested involving the children from our workshop in the further planning of the new primary school by being part of a focus group. The meeting may serve as a prime example of the exchange and social interaction going on between artists, children, local community and other agents within SEA.

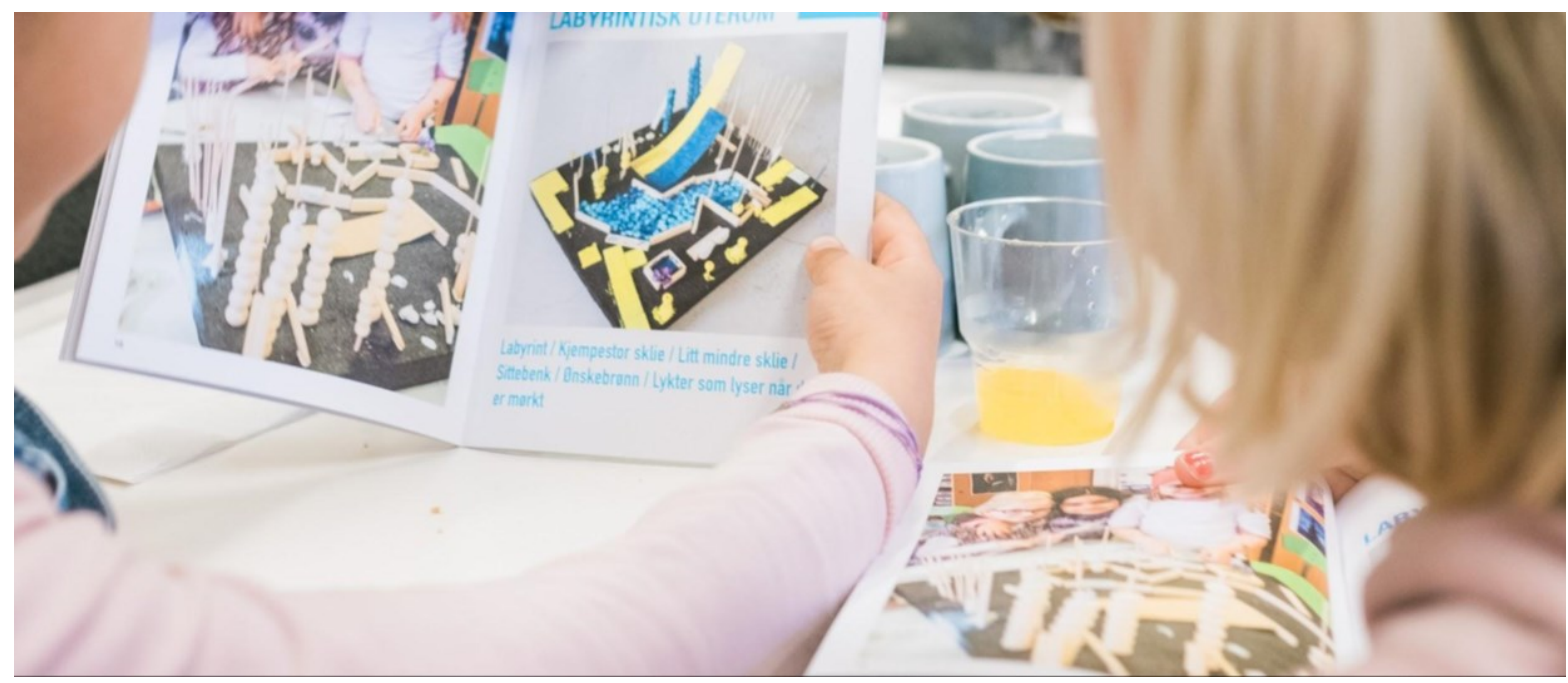

Figure 7. From the New School subproject, showing the children presenting their ideas to municipal officials. May 2019. Photograph: Johannes Laukeland Fester Sunde.

\section{Discussion}

\section{Haugerudbekken and socially engaged art}

We refer to Haugerudbekken as socially engaged art, as it revolves around community improvements through artistic practice, emphasising participation and exchange in the local community in Haugerud and Trosterud at a time of transformation. Working directly with the local community over several years, Haugerudbekken includes participants from outside the art world, engaging in a nonart community. Historically, relational aesthetics has often been conducted within the framework of the art world, which may be considered less risky than reaching out to the non-art community with all its elements of uncertainty (Helguera, 2011). In Living as form, Nato Thompson (2012) addresses the same issue, describing the safe haven of the art community as a limitation. He further describes a shift in the art world towards more long-term, community-based projects and a will to enter the world beyond the galleries and museums. As local artists working on Haugerudbekken, we exemplify this shift, situating our work within the local (non-art) community and involving members of this community.

Participation in a non-art community in SEA projects is diverse, and Helguera divides it into four categories; nominal, direct, creative and collaborative participation (2011, 
p. 15). Collaborative and creative participation tend to unfold over time, whereas nominal and directed participation tend to be short, one-off events. Helguera's term creative participation (shared responsibility for content) is a good description of how we work with the children. We present them with an overall framework and basic guidelines, regarding them as equal contributors in the further process of developing the content. Collaborative participation describes how we relate to the larger structure of the community (e.g., the school, the city district, landowners and other decision makers or partners) in our planning process and final production of public art.

Our workshops differ in terms of the time span and the age group of the participants. However, in spite of this variation, we still work within the same familiar community. According to Helguera (2011):

Most successful SEA projects are developed by artists that have worked in a particular community for a long time and have in-depth understanding of those participants. This is also why SEA projects, like exotic fruit, usually travel poorly when exported to other locations to be replicated. (p. 20)

As we ourselves are residents of the community, we are deeply embedded in the same context and surroundings as the children we work with, and have been so for a long time. When invited by Lier municipality in 2019 to do a participatory art project at Gullaug School in collaboration with The Cultural Schoolbag ${ }^{7}$, we found it challenging not being properly familiar with the local community we were to engage with. Project funding and time constraints limited research to one day, pre-arranged as a series of presentations organised by the municipality. We question whether we were able to create a proper framework that addressed and put into play preconceptions and potential change. As a result, the project became primarily educational and, in our opinion, failed to meet the requirement of art. Ideally we would need to operate as free agents for a longer period of time to become more deeply embedded in the context and to build relations for a better exchange.

Another project adhering to the importance of building relations over time and working with pupils is the artist-run Tenthaus ${ }^{8}$ and its partnership with Hersleb Upper

\footnotetext{
7 The Cultural Schoolbag (Den kulturelle skolesekken) is a national programme providing the experience of professional art and culture of all kinds for all school pupils in Norway.

8 Tenthaus Oslo is a project space initiated by Helen Eriksen, Ebba Moi and Stefan Schröder. https://tenthaus.no/
} 
Secondary School in Oslo. Tenthaus invites different artists to form unique projects for the school and its gallery, while continuity is maintained by Tenthaus itself. Longterm and mutually binding processes have shown to aid cooperation and exchange between all parties involved: teachers, artists and the participating pupils (Ulrichsen, 2017). The project The Quiet in the Land ${ }^{9}$ by France Morin is yet another testimony to the benefits of commitment over time and to knowing a community well. By moving to a region years prior to a project development, Morin gained the trust of the community and facilitated a successful engagement (Helguera, 2011, p. 20). In Haugerudbekken we believe that our in-depth knowledge of the area, our ability to work over a long time span, and the trust of the local residents aided successful outcomes in our project as well. Furthermore, in spite of our advantage as locals, we still find efforts to anchor the project locally and secure dialogue with all parties involved to be extremely time-consuming, albeit necessary. Hence, our findings give additional support to the notion of investing time and building relations as key success factors, as described in previous research and theory (Helguera, 2011; Thompson, 2012; Ulrichsen, 2017).

Another important finding in our project that aligns with Helguera's guidelines is the central role of communication in SEA. According to him, '[t]he key to a successful project lies in understanding the social context in which it will take place and how it will be negotiated with the participants or audience in question' (2011, p. 30). When we start a new project, we generally establish dialogue with a selected local school, as well as with potential landowners or other decision makers involved. In this dialogue we aim to optimise the practical framework around the project and adjust it to existing routines, structures and wishes. For instance, when opting to plant Crocus vernus, this suggestion was discussed with custodians as well as with the garden maintenance groups in the two condominiums. Knowing the limited financial resources available in the neighbourhood, it was important not to create additional work or costs for the condominiums.

Helguera (2011) further writes that 'honesty and directness are important in establishing a relationship of trust, and trust is key in engaging in productive activities with others' (p. 33). As we reach out and recruit children through the local schools, we benefit from existing structures and from the trust the community places in them.

\footnotetext{
${ }^{9}$ The Quiet in the Land is a non-profit art and education organisation founded and directed by the independent curator France Morin. http://www.thequietintheland.org/
} 
In communicating with other parts of the local environment (e.g., condominiums and voluntary organisations), we also benefit from our personal network. We strive to be clear and direct about our ambitions and goals for the project as well as about potential obstacles. For instance, we are currently developing a new subproject where we aim to develop a social sculpture in collaboration with local teenagers. However, future funding will decide whether the sculpture will actually be produced, and we have to be very clear about this so as not to disappoint our participants in case funding is not provided. This effort is perhaps especially important when involving children in order to facilitate their engagement in ongoing development processes.

\section{Teaching artist versus the community artist}

Although we work with children and youth in schools, it is important to point out that we are artists, not teachers or educators. We approach the children as professional artists, potentially adhering to definitions and frameworks of teaching artists (TA). Booth (2010) writes; 'A teaching artist is a practicing professional artist with the complementary skills, curiosities and sensibilities of an educator, who can effectively engage a wide range of people in learning experiences in, through and about the arts' (p. 2). We have no additional training or formal qualifications as educators, which potentially puts us at odds with this definition. Perhaps more importantly, education is not our primary goal. We aim to produce art, and we want to offer more art activities for children. When inviting the children to take part in our project, they are introduced to new knowledge in contemporary art. Although we find learning in and through the arts an extremely valuable side effect, we primarily consider the children to be our collaborators, not our pupils. Hence, we find it difficult to fully identify with 'an artist who teaches' (p. 24) described by Ulvund to be the unifying element across different definitions of TA. Furthermore, our independence departs from Ulvund's proposed model consisting of the following three elements: 1) teaching artist, 2) art programme (involving work related to learning both in and through the arts) and 3) creative partnership, referring to collaboration between TA and organisations/institutions with art education as the primary focus (2015).

Hence, perhaps the term community artist (CA) is more precise for how we conduct our work, particularly since it seems to more closely overlap with SEA. According to the Tate website ${ }^{10}$, community art is 'artistic activity that is based in a community

10 https://www.tate.org.uk/art/art-terms/c/community-art 
setting, characterised by interaction or dialogue with the community and often involving a professional artist collaborating with people who may not otherwise engage in the arts.' Arlene Goldbard (2006) avoids using the term community art, as it often includes conventional art based in a municipality setting. To avoid confusion, she prefers the term 'community artist' for individual (artists) who

actively engage in community relationships, often facilitated by service organisations, art-centers, places of worship, schools, universities and community centers. [...] In their creative endeavours, community-based artists value methods for building consensus, workable agreements and open and honest sharing. [...] They use art to transform neighbourhoods, communities and societies, often establishing enduring bonds that continue long after funding for specific initiatives has ended (Goldbard, 2006 pp. 11-12).

Booth (2010) describes a CA as someone who enriches community life, and draws a distinction between a TA and a CA by stating that: 'teaching artists aspire to have their learners engage in meaningful art making, and community artists seek to enhance the lives of communities through meaningful art making.' (p. 15). He further writes that both fields are evolving 'and the two are growing further into one another, [...] the boldest and most committed practitioners of these two fields are becoming one' (p. 16). This hybrid position is also found in the project Fargene $i$ Ski. ${ }^{11}$

Professional artists in this project enter the school setting providing children with new knowledge in art (Josef Albers' colour theory ${ }^{12}$ ) and collaborate with them on a contemporary public work of art reflecting on local identity through defining and working with colours identifying Ski. Despite the projects' similarities,

Haugerudbekken differs from Fargene $i$ Ski by aiming for a more durable presence for the work we produce with the children. Like many SEA projects in urban development projects, Fargene $i$ Ski will only last for a transitional phase while waiting for a permanent upgrade. Permanent installations produced in collaboration

11 Fargene i Ski (2017) is a temporary art project at Ski Station by artists Ebba Moi, Anas Salameh and Geir Yttervik and pupils from Ski Lower Secondary School. https://koro.no/prosjekter/follobanenski-stasjon/?highlight=fargene $\% 20 i \% 20$ ski

12 Josef Albers describes a triangular model of primary, secondary and tertiary colours in Interaction of Color (1975). 
with children and youth may have a stronger impact in fostering that engagement, pride and empowerment that are important in community development.

\section{Community improvement}

By inviting children to participate in shaping their local environment, we want to promote their engagement and ownership of Haugerud and Trosterud, challenging them to express their opinions within a sociopolitical arena. Helguera (2011) points out 'that is precisely what lies at the center of SEA: the idea that an intangible social interaction between a group of people can constitute the core of an artwork' (p. 73). In our opinion, the process of creating ambiguity, raising questions and involving the children is partly what defines and constitutes the art in Haugerudbekken as socially engaged art. We invite the children to take part in a process of dialogue, research and open, critical reflection, a process we find to be at the core of our project as well as of our practice as artists in general. Although the law prescribes that participation must take place in urban development processes ${ }^{13}$, the report Ung \& Ute. En studie av ungdom og unge voksnes bruk av uterom (Hagen et al., 2016) indicates that there is room for improvement. Although we lack documentation in terms of structured feedback, the general response we get from the children is pride in taking part. Furthermore, research indicates that inclusion of youth in urban development fosters local identity and ownership (Hagen et al., 2016). Hence, this is likely to be the case for the children we work with as well.

In addition to fostering ownership and engagement, our goal was to expand the offering of cultural activities for children in the area. Our workshops are open to everyone, but the children need to sign up. In Inkluderende kulturskole. Utredning av kulturskoletilbudet i storbyene. Bjørnsen (2012, p. 53) finds that in $49.3 \%$ of cases, signing up for cultural courses was a joint decision, whereas in only $24.2 \%$ cases it was initiated by the child and in $18.5 \%$ cases it was initiated by a parent. Bjørnsen argues that children from families considered to have 'high cultural capital' may be overrepresented (pp. 52-53). Although our workshops have been popular, it is difficult to estimate whether the diverse community is represented amongst our participants.

Our workshops take place in the children's schools, a location considered by most parents to be familiar and secure. By recruiting through established channels (the

\footnotetext{
${ }^{13}$ Plan- og bygningsloven, 2008, § 5-1.
} 
school), we manage to reach out to families that would otherwise not consider or perhaps be aware of other cultural offerings like the Oslo School of the Arts. According to Bjørnsen (2012), many minority families lack knowledge of what the Oslo School of Arts offers (p. 72). Furthermore, using the local school means there is no need for extra transportation. This could be important, given that transportation has been indicated as a potential barrier for participation in cultural activities for children in minority families (p. 86).

By including local children in cultural activities in their own neighbourhood and by meeting decision makers, we have in fact taken part in creating a more permanent local offering. Following our project and formation of Haugerud String Orchestra ${ }^{14}$, the Oslo School of the Arts has established a new local culture centres for children (Haugerud kulturstasjon) at Trosterud School, offering classes in music and visual arts. However, this does not automatically give all local children access to more cultural activities, given the implications of high participation costs as a possible barrier for children in low-income families (Bjørnsen, 2012). The Cultural Schoolbag is a cultural offering that overcomes such financial barriers. Since 2001, children in Norwegian schools have had the privilege of meeting professional artists during ordinary school hours, providing all children equal access to high-quality cultural experiences free of charge. However, an evaluation of The Cultural Schoolbag shows that both children and schools want to be more involved in the productions as equal partners. The children want dialogue, active participation, freedom to explore, and to have their input taken seriously, emphasizing workshop-based productions. In upper secondary schools, active participation is less important than for younger children, but relevance to their own lives and culture is emphasized across all ages (Breivik \& Christophersen, 2013). In Haugerudbekken we aim for broad inclusion as well as for children's active participation and influence. Given our goal of community improvement, this is particularly important in order to strengthen their engagement as well as to foster identity and ownership.

\section{Potential glitches, autonomy and aesthetic quality of art in SEA}

Although we conduct our project in the context of community improvement and find it is well received by the community and the district administration, it is important to underline that the project was not commissioned. In Living as form, Nato Thompson

\footnotetext{
14 The Haugerud String Orchestra was established in autumn 2017 and is run by parents. 45 children from 5-14 years old (2019) play the violin, viola, cello and double bass.
} 
raises several questions about potential glitches in socially engaged art. One is the risk of making oneself vulnerable to state instrumentalisation (2012, p. 32). This particularly applies when working with urban developers, community improvement initiatives and overall participation in development processes, as many SEA projects do, ours included. Since Haugerudbekken is initiated, defined and run by the artists themselves, we believe we have been able to avoid this potential glitch and ensure artistic autonomy in the project. Furthermore, it is realised primarily by external funding raised by the artists, thus underscoring this independence.

However, independence has also proven to be a challenge. One issue is the lack of access to updated information from the district administration, potentially losing track of milestone decisions in urban planning that affect our production. Another serious matter is maintenance of the installations produced. The lack of public ownership deprives them of the general maintenance and rehabilitation which commissioned works generally get. Through dialogue with landowners/condominiums, etc., we try to secure necessary structures for ownership and maintenance, but lack of experience and funding for our unofficial 'owners' tends to hand the workload of repairs and adjustments back to us as artists. With a growing body of public artwork, this is not sustainable over time, and given our goal of community improvement, run-down public art installations is not really a desired option.

Challenges with maintenance also arose for Bok på Veitvet ${ }^{15}$ (BPV), an open library installation at the Veitvet shopping centre in Oslo. The installation was a direct response to the wish of the people of Veitvet for the re-establishment of the public library they once had, contributing to vitalising the centre and serving as a place for social interaction. BPV was run based on trust and open access without any form of registration, and its collection was built up through donations. As it grew larger, the need to obtain organised and paid maintenance presented itself. However, municipal support was never granted for this, and in 2016 the artists behind BPV organised a bonfire made of books and the construction was passed on to a new owner. In

\footnotetext{
${ }^{15}$ Bok på Veitvet is an experimental self-organised library and independent art and architecture project, initiated in 2011 by Siri Jæger Brudvik, Sinikka J. Olsen, Kathleen Alana Morley, Ulrika Staugaard and Signe Vasshus.

https://bokpaaveitvet.tumblr.com/
} 
Bjørvika in Oslo, the Flatbread Society ${ }^{16}$ managed to participate in shaping development of the new district of Fjordbyen in a more permanent manner. Importantly, the project was commissioned by and produced in collaboration with the landowners and was initiated at an early stage in the area's development (Myrvold \& Wergeland, 2018). Although we are aiming to enter at an early stage in the development of a new park at Trosterud with Haugerudbekken's next project, there have been some challenges. Since there are no existing structures for including local initiatives of public art in urban development in Oslo (except for commissions), it is difficult to map out who to contact when and where. In fact, contrary to the case of the Flatbread Society, which dealt directly to the property owner, there are no official decision makers in our case, only a patchwork of municipal agencies with different agendas.

We continue to battle these challenges, however, given that the production of actual art pieces is a vital goal in our process. They are part of the artistic result of a process of exploration, inviting the wider community to take part in reflecting through aesthetic experience. As mentioned earlier, in line with SEA we find collaborating with and engaging the children to be equally as important as the result. This balance of process and artefact varies within SEA. For instance, Beer, Irwin, Grauer \& Xiong find the process to be more important than the artistic artefacts produced in The City of Richgate Project (2010). The importance of the artefact versus the process of collaboration is debated by Kester and Bishop (Bishop, 2006a; Bishop, 2006b; Kester, 2006). According to Bishop, Kester finds a SEA project to be a success as long as it is socially relevant and strengthens social bonds. This represents an ethical turn in art criticism, where SEA projects are judged merely on its working process. Finding this problematic, Bishop advocates critical thinking about SEA based on aesthetic criteria. She insists on the relevance of the artist's authorship while Kester would characterise this as putting the artist in a superior position and thereby degrading the participants' contribution. He emphasizes a consensual working process with an absence of any form of exploitation of the participants. We find ourselves adhering to both notions, as we attach equal importance to the process and to the artistic artefact, where one leads to the other (New School being the one exception). Like Kester, we emphasize equal collaboration with the children. However, we cannot put aside our competence as professional artists, so in line with

\footnotetext{
${ }^{16}$ The Flatbread Society is a long-term project initiated by Futurefarmers as a public art programme for Bjørvika in Oslo http://flatbreadsociety.net/
} 
Bishop, we are unwilling to compromise on aesthetic qualities or give up authorship. This is a challenging balance, but in our experience the children do not mind that we as professionals take on the role of editor and producer towards the end of the production. Though we lack structured feedback to document it, we notice that many children we collaborate with express pride in the way their work is taken seriously within this final stage of professionalisation. Perhaps it is the collaborative starting point that creates a flexible expectation towards the final result, as we have had similar experiences with other SEA projects working with adults.

\section{Summary and final thoughts}

This article aims to inform best practice for employing SEA in urban development based on reflections gathered through artistic practice. The following research questions were explored: how can employing SEA aid/contribute in and generate reflection within local improvement initiatives?; how can such practice engage children, and what are the key success factors?; and can SEA help improve communities while retaining the status of autonomous art, and what are the key challenges?

Our findings through our work with Haugerudbekken confirm that investment in time and contextual knowledge, establishing trust and making use of existing structures in the local community are key success factors. Our status as residents in the area in which we work is believed to support these aspects, and represents a unique position in our project. We also find that Haugerudbekken aids community improvement in terms of facilitating engagement among participants as well as producing public art and expanding the offering of cultural activities for youth and children. Collaboration between local artists and schools is found to be an efficient way of inviting children to participate in an artistic practice, and further engages them in local improvement processes. The cross-disciplinary nature of the project situates it within art, education and community improvement, and our position might best be described as a hybrid between community artist and teaching artist

Our status as independent artists makes Haugerudbekken less susceptible to instrumentalisation, thus ensuring autonomy. However, independence presents challenges in terms of lasting impact, and proper maintenance as structures for securing local initiatives for public art are lacking in the City of Oslo's current cultural management. Challenges like these and a growing demand for art to enter a societal context (like urban development) calls for more research addressing theory and improving best practice guidance (Christensen-Scheel, 2013). Our research is based on our experiences from artistic practice in Haugerudbekken. Future research might 
benefit from including data such as external observations and structured interviews in combination with such explorative processes, adding more structured collection and analysis of data.

\section{About the authors}

Katja Høst holds a master's degree in cognitive neuroscience from the University of Oslo as well as a fine art degree in photography from the Bergen Academy of Arts and Design. Her choice of media as an artist is highly project and context-dependent, varying from landscaping and relational aesthetics to video and photography. Social structures and practices, as well as identity, are recurring themes in her work, posing open ended questions as to how we define ourselves and govern our lives, as individuals or as a community.

Liva Mork holds a degree in fine art from the Oslo National Academy of the Arts. Mork works with site specific and socially engaged art, often in combination. 'Based on the history and identity of a place, her works highlight local qualities, distinctiveness and ongoing development and changes. Mork often engages local people to share their knowledge and take part in developing the projects. Mork has worked as Curator Education at the Nationalmuseum of Art, Architecture and Design and has held numerous workshops for children of all ages through DKS.

Høst and Mork have collaborated in the ongoing project Haugerudbekken since autumn 2016 and are currently working on the fifth subproject in Haugerudbekken.

\section{References}

Albers, J. (1975). Interaction of Color. New Haven, CT: Yale University Press.

Atkins, R. (2013). ArtSpeak: A guide to contemporary ideas, movements, and buzzword, 1945 to the Present. 3rd Edition. New York- London: Abbeville Press.

Bamford, A. (2012a). Arts and cultural education in Norway 2010/2011 (Report, Nasjonalt senter for kunst og kultur i opplæringen). Nord Universitet, Bodø. Retrieved from: https://kunstkultursenteret.no/wpcontent/uploads/2019/01/Arts-and-Cultural-Education-in-Norway-20102011.pdf.

Bamford, A. (2012b). Kunst- og kulturopplæring i Norge 2010/2011: sammendrag på norsk av kartleggingen 'Arts and cultural education in Norway' (Report 
summary in Norwegian, Nasjonalt senter for kunst og kultur i opplæringen). Nord Universitet, Bodø.

Beer, R., Irwin, R. L., Grauer, K., \& Xiong, G. (2010). Research and creation: Socially-engaged art in The City of Richgate Project. International Journal of Education through Art, 6(2), 213-227.

https://doi.org/10.1386/eta.6.2.213 1.

Bishop, C. (2006a). Social turn: Collaboration and its discontents. Artforum, 44(6), 179-183.

Bishop, C. (2006b). Claire Bishop responds. Artforum, 44(9), 24.

Bjørnsen, E. (2012). Inkluderende kulturskole. Utredning av kulturskoletilbudet $i$ storbyene. (Prosjektrapport No. 5, Agderforskning, Kristiansand). Retrieved from http://docplayer.me/3887192-Inkluderende-kulturskole.html.

Booth, E. (2010). The History of Teaching Artistry: Where we come from, are, and are heading. Retrieved from http://content.bandzoogle.com/users/joseherstrada/files/The History of Teac hing Artistry By Eric Booth.pdf - online article last accessed on 28 August 2020.

Bourriaud, N. (1998). Relational Aesthetics. Dijon: Les Presses du Réel.

Breivik, J. \& Christophersen, C. (2013). Den kulturelle skolesekken. Oslo: Kulturrådet.

Candy, L \& Edmonds, E. A. (2018). Practice-based research in the creative arts: Foundations and futures from the front line. Leonardo 51(1), 63-69. https://doi.org/10.1162/LEON a 01471

Christensen-Scheel, B. (2013). Application and Autonomy - The Reach and Span of Contemporary Art Didactics. Information, Nordic Journal of Art and Research, 2(2).

https://doi.org/10.7577/if.v2i2.729

de Assis, P., \& D'Errico, L. (Eds.). (2019). Artistic Research: Charting a Field in Expansion. Rowman \& Littlefield International.

Engen, L. (2020). Practice-led research in the art museum: Research on education practices led by the practitioners. Manuscript submitted for publication, Nordic Journal of Art and Research.

Goldbard, A. (2006). New Creative Community. The Art of Cultural Development. Oakland: New Village Press https://doi.org/10.2307/j.ctt21pxmht.

Gustavsen, K. \& Hjelmbrekke, S. (2009). Kulturskole for alle? Pilotundersøkelse om kulturskoletilbudet (TF-rapport nr. 255, Telemarksforskning). Retrieved from https://openarchive.usn.no/usn-xmlui/handle/11250/2439305. 
Hagen, A. L., Andersen, B., Brattbakk, I., Dahlgren, K., Ascher, B. E. \& Kolle, E. (2016) Ung \& Ute. En studie av ungdom og unge voksnes bruk av uterom. (AFI Rapport 6:2016). Retrieved from http://www.hioa.no/Om-OsloMet/Senterfor-velferds-og-arbeidslivsforskning/AFl/Publikasjoner-AFI/Ung-og-ute

Helguera, P. (2011). Education for Socially Engaged Art. New York: Jorge Pinto Books.

Hovik, L. (2014). De røde skoene: et kunstnerisk og teoretisk forskningsprosjekt om teater for de aller minste (doctoral dissertation). Norges teknisknaturvitenskapelige universitet, Trondheim. http://hdl.handle.net/11250/229706

Irwin, R. L., Beer, R., Springgay, S., Grauer, K., Xiong, G., \& Bickel, B. (2006). The Rhizomatic Relations of A/r/tography. Studies in Art Education, 48(1), 70-88. https://doi.org/10.1080/00393541.2006.11650500

Irwin, R., Jesús, M., Pardiñas, M. J., Barney, D., Chiung, J., Chen, H., ... MacDonald, A. (2017). A/r/tography Around the World: An Ever Evolving Methodology and Practice. In The Palgrave Handbook of Global Arts Education (pp. 475-496). https://doi.org/10.1057/978-1-137-55585-4 29

Kester, G. (2006). Another Turn. Artforum, 44(9), 22.

Myrvold, C. B. \& Wergeland, E. S. (2018). Participatory action in the age of green urbanism. How Futurefarmers leapfrogged the culture consumer? International Journal of Cultural Policy 24:3, 350-367. https://doi.org/10.1080/10286632.2016.1184658

Oslo Kommune. Planprogram for Trosterud og Haugerud. Retrieved on 24 January 2020 from https://www.oslo.kommune.no/slik-bygger-vi-oslo/planprogram-fortrosterud-og-haugerud/\#gref.

Oslo Kommune. Områdeløft for Trosterud og Haugerud. Retrieved on 24 January 2020 from https://www.oslo.kommune.no/slik-bygger-vioslo/groruddalssatsingen/omradeloft-trosterud-og-haugerud-2017-2023/\#gref.

Plan- og bygningsloven. (2008). Lov om planlegging og byggesaksbehandling (LOV2008-06-27-71). Retrieved from https://lovdata.no/dokument/NL/lov/2008-0627-71.

Rasmussen, B. (2012). Kunsten å forske med kunsten: et blikk på kunnen ut fra praksis-teori-relasjonen. Unpublished manuscript retrieved on 15 April 2020 from:

https://www.academia.edu/25793358/Kunsten \%C3\%A5 forske med kunste n Praksis teorirelasjonen.

Skajaa E. Arkitekter (2015). Sosiokulturell stedsanalyse Trosterud og Haugerud. Retrieved from: 
https://www.oslo.kommune.no/getfile.php/132222231496066238/Tjenester\%20og\%20tilbud/Politikk\%20og\%20administrasjon/Slik \%20bygger\%20vi\%200slo/Planprogram \%20for\%20Trosterud\%20og\%20Haug erud/Sosiokulturell\%20stedsanalyse $\% 20$ Haugerud\%20Trosterud.pdf

Thompson, N. (2012). Living as form: Socially engaged art from 1991-2011. Cambridge: MIT Press.

Ulvund, M. (2015). In the age of the teaching artist? What teaching artists are and do. Nordic Journal of Art and Research, 4(1). Retrieved from https://doi.org/10.7577/if.v4i1.1369.

Ulrichsen, G. O. (2017). Tenthaus Oslo - En inkluderende organisatorisk modell for framtidas kulturskoleelev. Journal for Research in Arts and Sports Education, 1(2), 55-68. Retrieved from https://doi.org/10.23865/jased.v1.541.

Østern, T. P. (2017). Å forske med kunsten som metodologisk praksis med aesthesis som mandat. Journal for Research in Arts and Sports Education, 1(5), 7-27. Retrieved from https://doi.org/10.23865/jased.v1.982.

\section{Websites referenced}

https://bokpaaveitvet.tumblr.com/ https://koro.no/prosjekter/follobanen-ski-stasjon/?highlight=fargene\%20i\%20ski https://nkl.snl.no/Siri Aurdal https://www.tate.org.uk/art/art-terms/c/community-art https://tenthaus.no/ http://www.thequietintheland.org/ https://trosterud.osloskolen.no/om-skolen/om-oss/var-profil/ 